\title{
SUSTAINABLE MAIZE (Zea mays L.) PRODUCTION UNDER DROUGHT STRESS BY UNDERSTANDING ITS ADVERSE EFFECT, SURVIVAL MECHANISM AND DROUGHT TOLERANCE INDICES
}

\author{
Ayman EL Sabagh ${ }^{1 *}$, Akbar Hossain ${ }^{2}$, Celaleddin Barutçular ${ }^{3}$, Abdelaal AA Khaled ${ }^{4}$, Shah Fahad ${ }^{5}$, \\ Folake B Anjorin $^{6}$, Mohammad Sohidul Islam ${ }^{7}$, Disna Ratnasekera ${ }^{8}$, Ferhat Kizilgeçi ${ }^{9}$, Gulab Singh \\ Yadav $^{10}$, Mehmet Yıldırım ${ }^{11}$, Omer Konuskan ${ }^{12}$, Hirofumi Saneoka ${ }^{13}$
}

${ }^{1}$ Department of Agronomy, Faculty of Agriculture, Kafrelsheikh University, 33156 Kafrelsheikh, Egypt

${ }^{2}$ Wheat Research Center, Bangladesh Agricultural Research Institute, Nashipur, Dinajpur-5200, Bangladesh

${ }^{3}$ Department of Field Crops, Faculty of Agriculture, Cukurova University, 01330 Adana, Turkey

${ }^{4}$ EPCRS Excellence Center, PPBL, Agric. Botany Dept., Faculty of Agriculture, Kafrelsheikh University, Egypt

${ }^{5}$ Agriculture department, The University of Swabi, Khyber Paktunkhwa, Pakistan

${ }^{6}$ Institute of Agricultural Research \& Training, Obafemi Awolowo University, Ibadan, Nigeria

${ }^{7}$ Department of Agronomy, Hajee Mohammad Danesh Science and Technology University, Bangladesh

${ }^{8}$ Department of Agricultural Biology, Faculty of Agriculture, University of Ruhuna, Sri Lanka

${ }^{9}$ Department of Field Crops, Faculty of Agriculture, Şırnak University, Şırnak, Turkey

${ }^{10}$ ICAR Research Complex for North Eastern Hill Region, Tripura Centre, Lembucherra, Tripura, India

${ }^{11}$ Department of Field Crops, Faculty of Agriculture, Dicle University, Diyarbakır, Turkey

${ }^{12}$ Department of Field Crops, Faculty of Agriculture, Mustafa Kemal University, Hatay, Turkey

${ }^{13}$ Plant Nutritional Physiology, Graduate School of Biosphere Science, Hiroshima University, Japan

Received - December 12, 2017; Revision - February 05, 2018; Accepted - March 31, 2018

Available Online - April 25, 2018

DOI: http://dx.doi.org/10.18006/2018.6(2).282.295

\section{KEYWORDS}

Maize

Agronomical

Biochemical

Physiological characters

\begin{abstract}
Maize is an essential dietary component in human food and in animal feed formulation. With the rising trend of global climate change, grain yield and quality losses of maize are expected to increase, because of various biotic and abiotic stress in all over the world. Among these, drought is most considerable one; it remarkably influences growth and yield traits of maize. Hence, the improvement of drought tolerant maize genotypes has potential to stabilize and even though increases the grain yield of maize. Therefore, developing cultivars tolerant to drought stress is a challenge for breeders. There are two ways to mitigate drought stress in maize production, either by developing and practicing improved drought
\end{abstract}

* Corresponding author

E-mail: ayman.elsabagh@agr.kfs.edu.eg (Ayman EL Sabagh)

Peer review under responsibility of Journal of Experimental Biology and Agricultural Sciences.

Production and Hosting by Horizon Publisher India [HPI] (http://www.horizonpublisherindia.in/).

All rights reserved.
All the article published by Journal of Experimental Biology and Agricultural Sciences is licensed under a Creative Commons Attribution-NonCommercial 4.0 International License Based on a work at www.jebas.org.

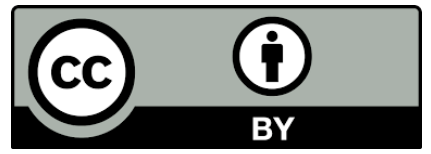




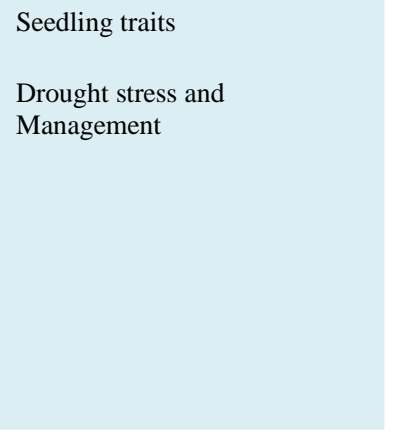

\section{Introduction}

Maize is an important cereal crop with a wider range of uses than other cereals (Olaniyan, 2015). Its demand is increasing day by day because of diverse uses, include human consumption, livestock feed formulation, pharmaceutical, textile industries and biofuel (Ali et al., 2010). However, the production capacity of maize is not adequate to meet the utilization demand. Therefore, to meet the increasing demands greater efforts should be taken under different environmental conditions (Karasu et al., 2015). Maize is a necessary crop which is using as food, fodder, fuel, as well as in the manufacture of industrial products. Furthermore, oil of maize is also appropriate for human consumption due to the presence of unsaturated fatty acids.

Among the abiotic factors, drought is one of the major environmental constrains, that limits the productivity of crop (Hossain et al., 2013; Hassan et al., 2016), through changing the growth, physiology and metabolism of plants (Lunde et al., 2007; Islam et al., 2011). Drought stress is a major constraint to agricultural production in many developing countries of the arid and semi-arid regions of the world (Turhan \& Baser, 2004; Golbashy et al., 2010). Grain yield is the most commonly studied parameters; therefore primary aim of any research is to increase the grain yield (Ignjatovic-Micic et al., 2014). While, grain quality parameters have less attention but various studies have suggested that water stress reduced the various quantitative or qualitative traits such as grain protein, oil and starch content (Boyer \& Hannah, 2001; Rehman et al., 2011; Rashwan et al., 2016; Barutçular et al. 2016 b; Barutçular et al. 2016d ; EL Sabagh et al.,2017b; EL Sabagh et al., 2018; Abdelaal et al., 2017). According to Zhao et al. (2009) maize protein components are sensitive to drought stress when it occurs during grain filling stage.

Drought affects the plant from seedling to maturity and yield reduction at the reproductive phase is greater than the vegetative and grain filling periods (Khalili et al., 2010). According to Khodarahmpour \& Hamidi (2012) drought stress at the vegetative, pollination and grain filling periods can cause losses in maize yield by 15,40 , and $60 \%$, respectively. Drought causes higher yield reduction in maize than those caused by other potential climatic factors (Shaw, 1977). When it occurred during silkingtasseling phase (flowering and pollination) it reduces grain yield by as much as $7 \%$ per day of stress. Prolonged period of drought shortened the grain filling period and finally reduced grain yield of maize (Gooding et al., 2003). While, developing cultivars tolerant to drought is challenging for breeders (Timsina \& Connor, 2001).

There are two ways to mitigate stresses, either by developing and practicing improved stress management practices, or by developing and using drought-tolerant cultivars (Farooq et al., 2011). Therefore, it is very essential to improve existing as well as new breeding methods by using multi-disciplinary approaches for developing good genotypes that are tolerant to abiotic stresses specially drought for Arid and Semi-Arid environments of the globe (Cairns et al., 2012a).

Stress tolerance indices are useful tools to determine high productivity and stress tolerance potential of genotypes of crop. It has been commonly accepted that identifying high productivity genotypes under stress and non-stress conditions are more beneficial than the developing new verities (Lan, 1988; Mitra, 2001; Jafari et al., 2009; Naghavi et al., 2013; Barutçular et al., 2016a). For screening drought-tolerant genotypes, the most commonly used stress tolerance indices are stress susceptibility index (SSI) (Fischer \& Maurer, 1978), stress tolerance index (STI), tolerance index (TOL) (Rosielle \& Hamblin, 1981), yield index (YI) (Gavuzzi et al., 1997), yield stability index (YSI) (Bouslama \& Schapaugh, 1984), mean productivity (MP) and geometric mean productivity (GMP) (Fernandez, 1992).

Present review aimed to understand the adverse effect of drought stress on growth, yield traits, physiological and biochemical process of maize and also attempt to identify the survival mechanism under drought stress. In this review, author also tried to identify the important drought tolerance indices that help in 


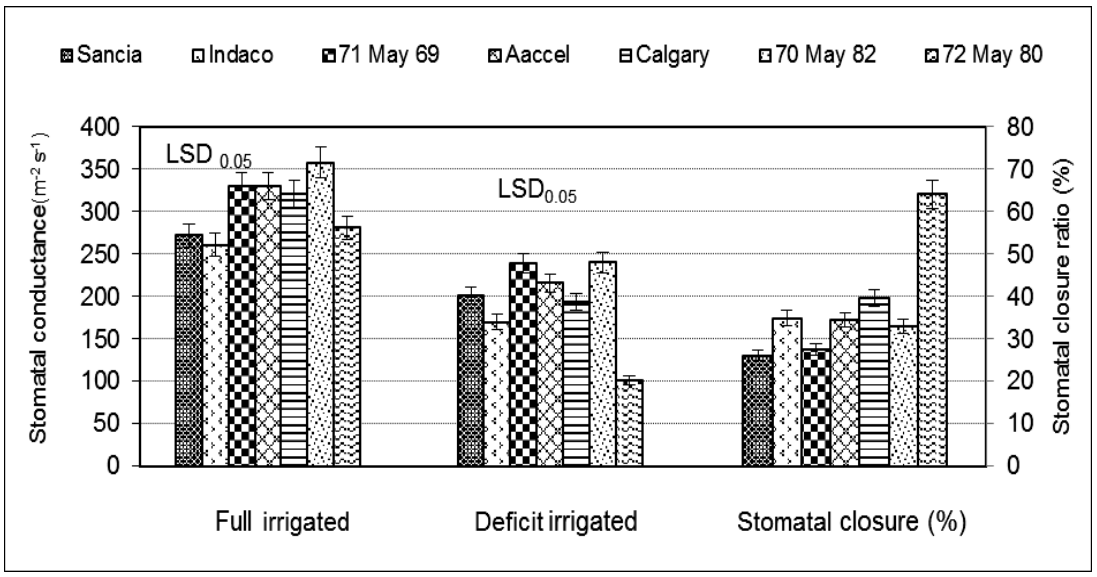

Figure 1 Stomatal conductance $\left(\mathrm{mmol} \mathrm{m}^{-2} \mathrm{~s}^{-1}\right)$ of maize genotypes recorded at 7 days after anthesis under full irrigation and deficit irrigation regimes (EL Sabagh et al., 2017a).

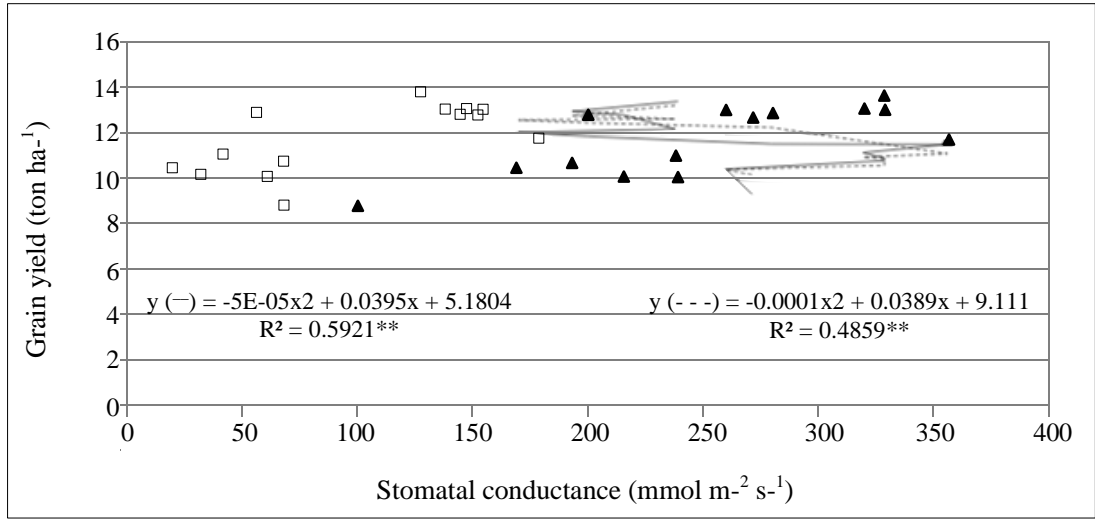

Figure 2 Relationships between grain yield and stomatal conductance of maize at $7(\Delta, \boldsymbol{\Lambda},-$ - - ) and $21(\square, \mathbf{\square},-)$ days after anthesis under full irrigation $(\boldsymbol{\Lambda}, \boldsymbol{\bullet})$ and deficit irrigation $(\Delta, \square)$ regimes (EL Sabagh et al., 2017a).

selection of stress tolerant genotypes and can use as selection criteria.

\section{Influence of drought on establishment of maize seedling}

Drought is one of the main abiotic stresses which limiting crop growth rate and have negative consequences on various cellular activities. Wenkert et al. (1978) reported reduction in cellular elongation and carbohydrate wall synthesis in germinating seed when they exposed to water stress. Detrimental effect of drought stress on the initial phase of growth and seedling establishment of maize plants cannot be ignored (Shao et al., 2008). Drought stress reduced the rate of seed germination in maize crops; however, maize varieties respond positively in response to drought stress (Anjorin et al., 2017). The drought tolerant maize genotypes germinated earlier than the non-drought tolerant maize varieties under critical level of soil moisture when maize varieties were subjected to varying water regimes. Naturally, plant employs several adaptive measures to cope with harsh weather conditions, such adaptive measures bring about changes or adjustment in the physiological and biochemical processes of plant. Closing of stomata, number of leaves formed per plant, total leaf area produces, and plant height are reduced to minimize water loss under water shortage (Boyer \& Kramer, 1995; Anjum et al., 2011). Similarly, Saliendra \& Meinzer (1991) also reported that reduction in water potential induces stomatal closures resulting in a decline in the rate of photosynthesis, leaf growth and ultimately yields.

Two types of organic solutes (i.e., nitrogen-containing compounds and the hydroxyl compounds) produce by plants under stress condition for metabolic adjustment these compatible organic 
solutes contains sugars, polyols, betaines and proline (Yancey et al., 1982). In young maize water stress metabolites such as soluble sugar and proline increased with increased water stress while starch content and relative water content reduced with increased drought (Izanloo et al., 2008; Nayer \& Reza, 2008; Anjorin et al., 2016). Selection for drought tolerant plant using the biochemical component have been described as a fast indirect and reliable method of drought tolerant selection even for plants at the seedling stage (Schiop et al., 2015). However, drought tolerant maize varieties that produced highest antioxidant metabolites are not usually the highest yielding varieties (Anjorin et al., 2016; Anjorin et al., 2017). Similarly, Nazarli \& Faraji (2011) suggested that several factors should be put into consideration when selecting for drought tolerance in maize. They also noticed that drought tolerance is a complex process that depends on action and interaction of different physiological, biochemical parameter as well as different morphological traits, such as leaf rolling, efficient rooting system, etc.

\section{Physiological responses of maize verities under drought}

The performance of crop under drought condition is a complex phenomenon, when drought occurs during the reproductive growth stage, plant reduce the demand for carbon by decreasing the size of sink which eventually diminished the grain yield of crop (Reynold et al., 2006). Acclimation of different organic solutes make changes in the various physico-biochemical processes changes such as plant structure, growth, osmotic potential of plant tissue and antioxidant defenses in plants lead to adapt/survive plant under drought condition (Duan et al., 2007; Chen et al., 2010; Köksal, 2011). While, in most cases grain yield and drought adaptation are complex phenomenon (Bruce et al., 2002). Also, in drought breeding programmes, identification of phenotypic, ideotype traits and donors are important (Cairns et al., 2012b). The changes in leaf morphology induced by drought caused higher reflectance in the visible spectra between stressed and unstressed maize leaves (Genc et al., 2013).

Physiological trait such as stomatal conductance is an important feature which influenced yield significantly under drought stress and it is an important indirect drought tolerant crop selection criterion (Dodd, 2003; Koc et al., 2008). Stomatal conductance is a key trait of photosynthetic leaf that significantly influenced by water stress (Jiang et al., 2006). But, soil drying/drought leads to a decrease in stomatal aperture and stomatal conductance (Songsri et al., 2013; EL Sabagh et al., 2017a; Barutçular et al., 2017), therefore, plants under drought condition exhibited reduced rate of photosynthesis. Higher stomatal conductance could be a major determinant for high grain yield in maize under stress condition at grain filling stage (Munjal \& Rana 2003). Drought could lead to increased stomatal density and reduced stomatal size, for adaptation of plants under drought stress (Martinez et al. 2007). In maize, some drought tolerant genotypes reduced leaf stomatal conductance more on the onset of drought (Ray \& Sinclair, 1997). A significant genotyic variation in relation with stomatal conductance of maize genotypes recorded at 7 and 21 days after anthesis under full irrigation and deficit irrigation regimes (EL Sabagh et al., 2017a; Figure $1 \&$ 2). Similarly, Bahar et al. (2009) found a positively correlation effect between stomatal conductance and yield. Similarly, Kolb \& Robberecht (1996) reported a significant association between stomatal conductance and transpiration. However, a non-significant correlation between stomatal conductance and grain yield was also reported by Anjum et al. (2008). The remarkable genotypic variation in the stomatal conductance was observed by Bahar et al. (2009).

Generally, reduced canopy senescence and higher leaf chlorophyll are correlated with the increased grain yield of hybrids under well-watered conditions (Lee \& Tollenaar, 2007; Barutçular et al., 2016c). A significant relationship was recorded between SPAD value and grain yield of wheat after anthesis, while no significant association was observed during middle and late grain-filling stages (Monneveux et al., 2008; Akhter et al., 2016). Further, SPAD values could be used as a criterion of grain yield in wheat (Barutçular et al., 2016e). Athar \& Ashraf (2005) found that water deficit in root zone caused a reduction in leaf area, chlorophyll and photosynthetic rate of maize. The reduction in relative water contents under drought resulted in wilting, stomatal closure and growth reduction (Lawlor \& Cornic, 2002; Unyayar et al., 2004). Abiotic stresses led to changes in the membrane permeability (electrolyte leakage) of plants (Abdelaal et al., 2018).

\section{Effect of drought on grain yield and yield components of maize}

According to Abd El-wahed et al. (2015); EL Sabagh et al. (2017a); Abdelaal et al. (2017), the grain weight and other yield traits' values under well-irrigated condition (without moisture stress) were increased significantly as compared with drought condition. Yield attributes such as stem length, ear height, number kernels row ${ }^{-1}$, grain weight, grain yield, biomass yield and harvest index of maize were adversely affected by drought stress (EL Sabagh et al., 2017a). The similar type impacts of water deficit and well-water regimes on the yield traits and grain yield of maize had been reported in several studies (Cakir, 2004; Moser et al., 2006; Rivera-Hernandez et al., 2010). Shoa Hoseini et al. (2007) and Golbashy et al. (2010) reported that under drought stress, reduction in the total grain yield of maize are attributed to the reductions in number of kernels per row and total number of kernels per ear. Under water stress, kernels plant ${ }^{-1}$ of maize was 
decreased significantly that ultimately lead to decrease the grain yield of maize (Yazar et al., 1999).

Water stress during the critical stage of silking to early grain filling, caused inhibition in photosynthesis rate and consequently lowers the carbohydrate reserves that are insufficient to support optimum reproductive development; causes reduction in the photosynthates mobilization to seeds and there by reduction of grain weight (Eck, 1986). While, Kamara et al. (2003) found that disruption of irrigation at grain filling period decreasing grain weight, due to decrease in the remobilization of photosynthates into the grains. Other researchers noticed that the reduction in grain yield was primarily associated with reduction in number of kernel and secondarily kernel weight when drought stress was imposed during the vegetative and reproductive growth phases in maize (Pandey et al., 2000; Shoa Hoseini et al., 2007; Golbashy et al., 2010). Likewise, drought stress between initial flowering and grain filling stage reduced total grain yield primarily by reducing vegetative growth, which consequently resulted in reduced number of grain and grain yield (Frederick et al., 2001; Leta et al., 2001; Karimian et al., 2005; EL Sabagh et al., 2017a). While, drought stress at pollination stage affects grain formation of maize because of reduced photosynthesis, leading to assimilate deficiency, increase production of sterile pollen ultimately reduced number of grain per ear (Setter et al., 2001; Araus et al., 2010). Farooq et al. (2009) noticed that the deficiency of water vegetative to reproductive stage of maize leads to severe reduction in yield of crop. Earlier findings also reported that anthesis period is the most sensitive stage to drought in maize growth and development that ultimately reduced that grain yield (Cakir, 2004, Zharfa et al., 2011; EL Sabagh et al., 2015a; Barutçular et al., 2016a). Stone et al. (2001), Bänziger et al. (2002) and Zharfa et al. (2011) established a strong relationship between biomass accumulations (especially after silking) with grain yield. Furthermore, they also observed that the higher growth rate ability of cultivars reduced when they are exposed to water stress condition.

\section{Genotypic and phenotypic variation of maize genotypes under drought stress}

The significant variations among different maize genotypes with respect to grain yield and yield traits indicate the existence of genetic variation and possibility of selection for drought tolerance genotypes (EL Sabagh et al., 2017a). Reality of high differences among maize hybrids for drought tolerance had been reported by several investigators (Golbashy et al., 2010). The adverse influence of drought stress on the physiological traits of maize genotypes by reducing the production of dry matter disrupts the partitioning of carbohydrates to grains and decreasing the harvest index (Mostafavi et al., 2011). Anjum et al. (2011) observed a positively reduction of kernels row ${ }^{-1}$, kernel weight, kernels $\operatorname{cob}^{-1}$, grain yield, biological yield and harvest index of maize, when a maize plant was exposed to drought at the tasseling stage. Pandey et al. (2000) noticed that yield loss in maize genotypes between 22.6 to $26.4 \%$ caused by deficit water which ultimately reduced the number of kernels as well as grain weight.

\section{Correlation analysis between growth traits and yield attributes}

A suitable index should have a positive relationship with grain yield under stress conditions as reported by Golbashy et al. (2010) and Shoa Hoseini et al. (2007). Positive relationship coefficient was reported between grain yield and grain weight while kernels row $^{-1}$ was negatively associated with yield. Also, a significant relationship was reported between grain yield and drought resistance index (DRISC) $(\mathrm{r}=0.784, \mathrm{P}<0.037)$ (in the young leaves) under water stress environment (EL Sabagh et al., 2017a and Figure 2). Higher value of DRISC indicated highly resistance of maize genotypes under drought stress and might be used as drought tolerant genotypes for future breeding program. Stress tolerance index (STI) is also an important index that could be used to identify stress-tolerant high yielding genotypes (Sanjari, 2000; Kharrazi \& Rad, 2011). The correlation between stomatal conductance and grain yield were significant (but non-significant) at early milky stage $(\mathrm{r}=0.165)$ but non-significant at late milky stage $(r=-0.234)$ under normal watering, while no positive correlation between stomatal conductance and grain yield was observed at early maturity stage under water stress condition (Bahar et al., 2009). Maize grain yield was negatively correlated with root and leaf growth rates under water stress condition. However, Zharfa et al. (2011) reported strong correlations between root growth and maize grain yield under normal condition.

\section{Selection of drought tolerant genotypes based on tolerance indices}

Drought tolerance is often a tedious process because of complex genotypes and environment interactions (Fernandez, 1992; Naghavi et al., 2013). Several drought tolerance indices are used to identify drought-tolerant genotypes, based on yield loss as compared with normal conditions (Mitra, 2001; Jafari et al., 2009; Naghavi et al., 2013). Barutçular et al. (2016a) observed a high relationship between the grain yield and drought tolerance indices and also noticed that these are most suitable in selection indices to identify the best maize genotypes for drought condition (Figure $3 \& 4$ ). Drought sensitivity and tolerance indices of the maize genotypes were determined on the basis of grain yield obtained under stress condition.

The relationship between grain yield and drought tolerance indices might be used to screen a good genotypes which are 


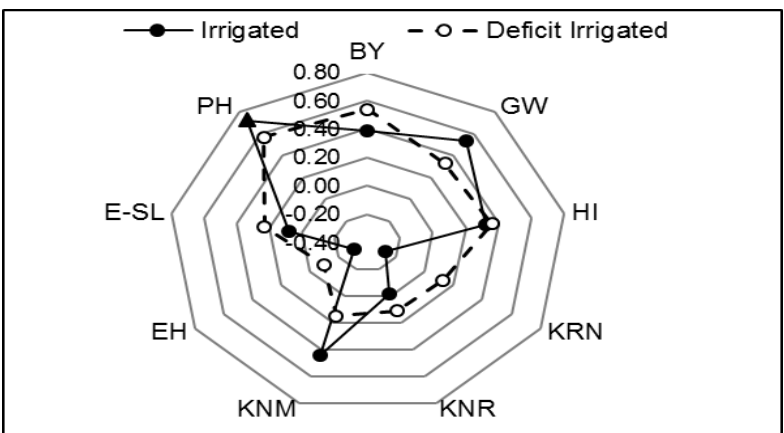

Figure 3 Pearson correlation coefficient between grain yield and agronomic traits of maize hybrids under irrigation regimes (Two years average) (Barutçular et al., 2016a), here $\dagger$ indicates significant at $\mathrm{P}=0.057$ level; $\mathrm{PH}$, plant height; E-SL, ear-up stem length; $\mathrm{EH}$, ear height; KRN, kernel row number per-ear; KNR, kernel number per row; KNA, kernel number per area; GW, grain weight; $\mathrm{HI}$, harvest index; GY, grain yield; BY, biomass yield.

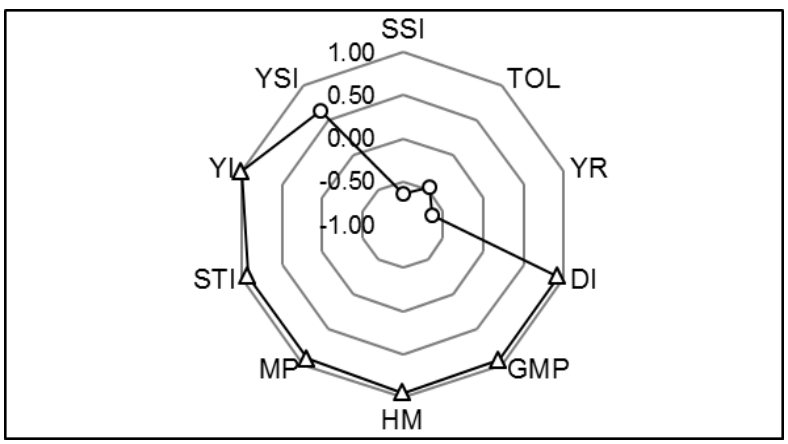

Figure 4 Pearson correlation coefficients between grain yield and drought indices (Two years average) (Barutçular et al., 2016a), here ** indicate significant $\mathrm{P}<0.01$ level; SSI, stres susceptibility index; TOL, tolerance index; YR, yield reduction ratio; DI, drought resistance index; GMP, geometric mean productivity; HM, harmonic mean; MP, mean productivity; STI, stres tolerance index; YI, yield index; YSI, yield stability index. suitable to grow under drought condition (Barutçular et al., 2016a; Figure $3 \& 4$ ). Genotypes with high values of STI, GMP and MP can be selected as drought tolerant genotypes (Hossain et al., 2013; Barutçular et al., 2016a; Figure 3 \& 4). Furthermore, Hossain et al. (2013) and EL Sabagh et al. (2017a) noticed that TOL and SSI appeared to be most suitable indices for selection of high yielding genotypes under drought stress. The genotypes with high values of yield stability index (YSI), drought resistance index (DI) and harmonic mean (HM) might be selected as tolerant genotypes to water stress ( Barutçular et al., 2016a and Figure 3 \& 4). In the view of Abdipour et al. (2008), MP, GMP and STI were suggested as the best indices for separating drought tolerant genotypes. Khalili et al. (2012) and Jafari et al. (2009) observed that GMP, MP, and STI indices were significantly associated with yield under well-irrigated and drought stress conditions and could be used in maize breeding programs as a reliable selection methods to produce drought tolerant maize hybrids.

\section{Approaches for enhancing the productivity of maize}

Plants can survive under different stress conditions by mobilizing various defense mechanisms as well as altering their physiological metabolism and growth pattern (Mittler, 2002). Various previous investigations revealed that severe drought condition critically affects the biochemical, physiological and morphological procedure of maize crop (Basu et al., 2010; EL Sabagh et al., 2016a). Zhang et al. (2009) reported that during osmotic stress (drought), an increase in external osmolarity that ultimate result in an efflux of water from the interior, leading to a reduction in the turgor pressure in the cell as well reduction in the cytoplasmic volume.

Plant growth regulators also play significant role in drought tolerance, these growth regulator always work in coordination with several growth processes ( Anjum et al., 2011; Abo-Youssef et al. 2017; Abdelaal et al., 2017, Figure 5). Various organic

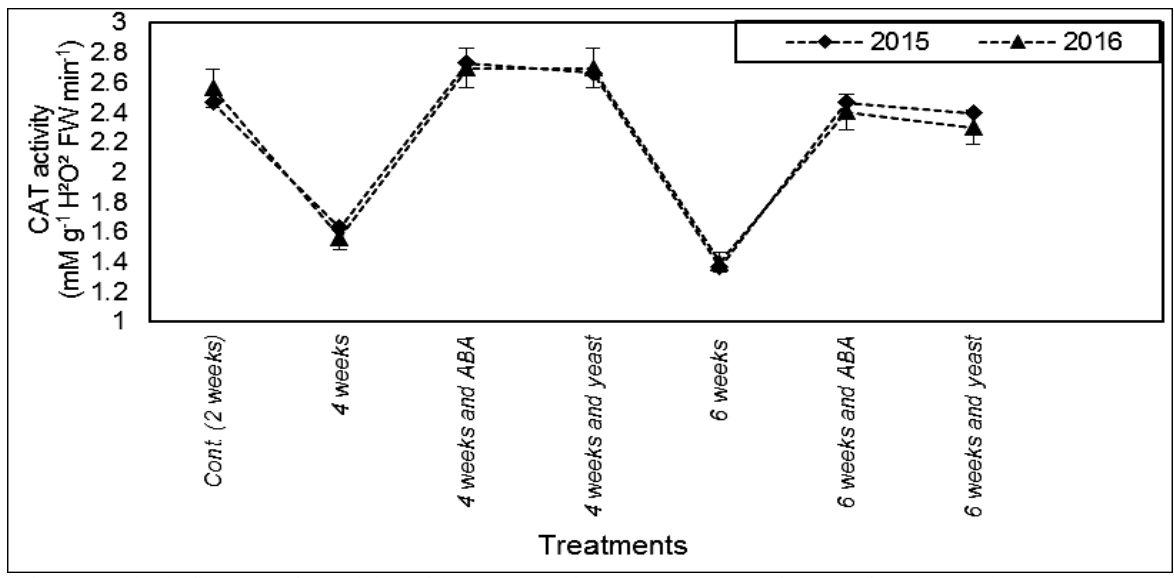

Figure 5 The influence of abscisic acid (ABA) and yeast on CAT activates of maize under water stress conditions during 2015 and 2016 seasons (Abdelaal et al., 2017). 
compatible solutes include proline (PRO), glycine betaine (GB), trehalose (Tre), salicylic acid (SA), ascorbic acid (AsA) and several others before or during environmental stress can protect plants against stress damage through increasing inside plant solutes (Monyo et al., 1992; Mattioli, 2009; Ali \& Ashraf, 2011; Kaya et al., 2013; Reddy et al., 2013).

Several studies reported that exogenous application of proline (PRO) help to survive plant under different abiotic stresses including drought (Ali et al., 2007; Ali et al., 2008). Although little attention has been given to the role of PRO in uptake and accumulation of inorganic nutrients in plants, however, many studies have given much attention on stress tolerance in plants as a compatible osmolyte for osmotic adjustment during drought stress (Ali et al., 2007; Ali et al., 2008). Role of glycine betaine (GB) as an effective compatible solute against various environmental stresses including drought is well established (Ashraf \& Foolad, 2007; Zhang et al., 2009). Further, Salicylic acid (SA) acts as an endogenous signal molecule responsible for inducing tolerance of plants under environmental stress (Gunes et al., 2005). It is also involved in biochemical pathways, stress and disease resistance and many other plant responses (Kovacik et al., 2009). According to Elwana \& El-Hamahmy (2009), SA enhanced photosynthetic rates, leaf area and plant dry matter production (Khan et al., 2003). Salicylic acid also acts as a potential non enzymatic antioxidant and help in adjust of plant physiological activity like photosynthesis rate (Arfan et al., 2007). Gharib et al. (2016) reported effect of SA on the growth and yield components of wheat crop under drought stress conditions.

Further, exogenously applied ascorbic acid (AA) ameliorates adverse effects of drought (Dolatabadian et al., 2010; Khalil et al., 2010). It has been reported that maintenance of water status is regulated by stomatal conductance and rate of transpiration and AA played significant role in these two physiological processes
(Ashraf, 2009). Ascorbic acid has been also used to prevent the unfavorable impacts of salt stress in several crops (Khan et al., 2010). Some other researchers (Dolatabadian et al., 2010; Dolatabadian et al., 2010; Khalil et al., 2010; Yazdanpanah et al. 2011) also reported that under stress environments, the ascorbic acid plays a positive role in adjustment of mechanisms of photosynthesis and the defense roles against oxidative stress.

Abscisic acid (ABA) could be enhancing plants resistance to environmental stresses (Giraudat et al., 1994). Pre-soaking seed treatment with ABA was positively improving the antioxidant enzymes activity seedlings of maize under water stress conditions (Jiang \& Zhang 2002). Application of ABA stimulated the morphological and anatomical modify which could provide the roots to breakthrough compacted soil (Hartung et al.,1994). Abdelaal et al. (2017) found that grains ear ${ }^{-1}, 100$ grain weight and grain yield of maize was highly influenced by abscisic acid (ABA) and yeast under water stress conditions (Figure 6). The active yeast extract significantly improved growth and agronomical attributes of plants (Rania Nassar et al., 2011; Hammad, 2008). Further, the agronomical traits positively enhanced in stressed treated plants in maize and improved the growth characters and antioxidant enzymes activity by abscisic acid (ABA) and yeast application, Figure 5 and 6 (Abdelaal et al., 2017). Application of ABA significantly improved the antioxidant enzymes activity under drought stress in corn plant (Lee \& Luan, 2012; Abdelaal et al., 2017).

The Fertilizer application management, balanced nutrients in plants are a major element to enhance the growth and productivity of crop under semiarid conditions (Amanullah et al.,2016). Intensive using of mineral fertilizers a main problem to environmental and production cost (EL Sabagh et al., 2015c; EL Sabagh et al., 2016b; EL Sabagh et al., 2016c). The implementation of organic and inorganic fertilizers combined

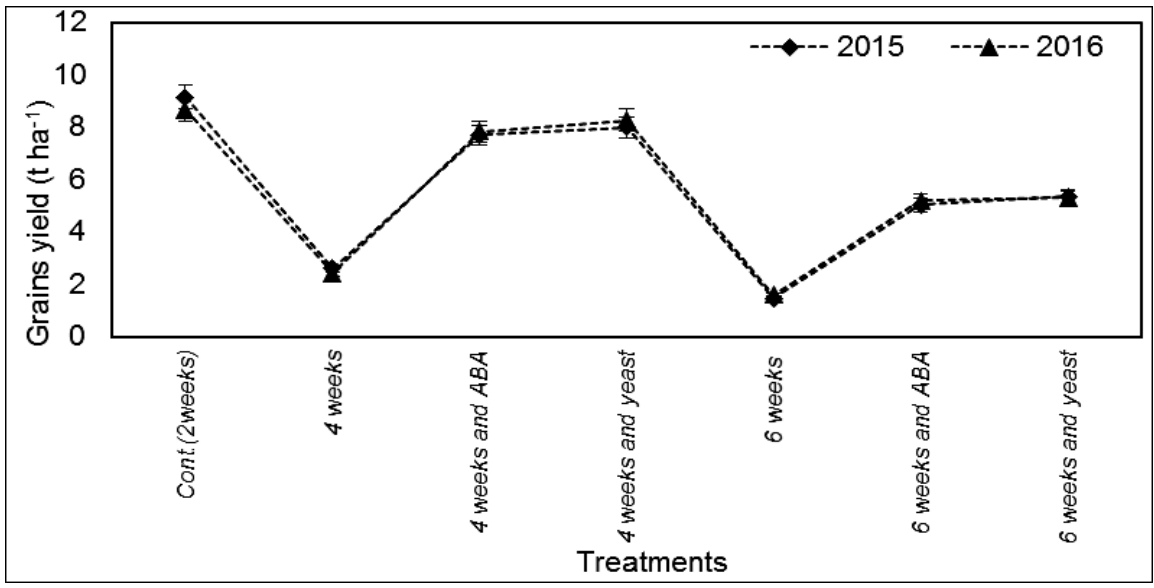

Figure 6 Grain yield as influenced by abscisic acid (ABA) and yeast of maize plants under wate stress conditions during 2015 and 2016 seasons (Abdelaal et al., 2017).

Journal of Experimental Biology and Agriculture Science http://www.jebas.org 
might improve the activities of soil and nutrient availability (He \& Li, 2004; Nasim et al., 2012). Application of organic fertilizers is very effective for reducing negative effect of stress environment and to increase the yield and quality of crops (Ahmad \& Jabeen, 2009; EL Sabagh et al., 2015b). While a positive relationship between amount of irrigation water and grain yield at different Farmyard manure (FYM) treatments under drought stress condition, indicating that FYM in combination with amount of irrigation help to survive plants under deficit water stress condition (Abd El-Wahed et al., 2015). Organic fertilizers might play an important role to solve environmental pollution problems that caused by agroindustrial wastes (Preap et al.,2002 ; Gharieb et al. , 2016).The combined chemical and poultry manure fertilization (50:50) produced the maximum yield and its traits of maize (Nasim et al. (2012). According to Azab (2016) application of half rate of the chemical NPK combined with bio-fertilizers was effective and logic to achieve the maximum productivity under the condition of investigation in maize.

\section{Conclusion}

From the present review, it can be concluded that, with the rising trend of global climate change, especially due to drought stress, growth and yield of maize reduce significantly all over the world especially in Arid and Semi-Arid region of the world. Hence, the use of drought tolerant maize genotypes has potential to stabilize the grain yield of maize. Therefore, developing cultivars tolerant to drought stress is challenging for breeders to face the future climate changing condition. Suitable stress tolerance index should be have a positive or negative relationship with grain yield of maize under drought stress. Plant growth regulators, nonenzymatic antioxidants especially osmoprotectants as exogenous applications and soil application of fertilizer (organic and inorganic) can also modify the morphological, physiological as well as biochemical process of plants for better adaptation under harsh environments.

\section{Conflict of interest}

All the authors declare that there is no conflict of interest.

\section{References}

Abdelaal Kh AA, Hafez YM, EL Sabagh A, Saneoka H ( 2017) Ameliorative effects of abscisic acid and yeast on morphophysiological and yield characters of maize (Zea mays L.) plants under water deficit conditions. Fresenius Environmental Bulletin 26:7372-7383.

Abdelaal Kh AA, Omara IR, Hafez MY, Esmail SM, EL Sabagh A (2018) Anatomical, Biochemical and Physiological Changes in Some Egyptian Wheat Cultivars Inoculated with Puccinia graminis f. sp. tritici. Fresenius Environmental Bulletin 27: 296305.

Abd El-wahed MH, EL Sabagh A, Zayed A, Sanussi A, Saneoka $\mathrm{H}$, Barutçular C (2015) Improving yield and water productivity of maize grown under deficit-irrigated in dry area conditions. Azarian Journal of Agriculture 2: 123-132.

Abdipour M, Rezaee AH, Hooshmand S, Bagherifard G (2008) Evaluation of drought tolerance of indeterminate soybean genotypes in flowering and seed filling stages. Journal of Research in Agricultural Science 4: 140-150.

Abo-Youssef M, EL Sabagh A, Abo-Gendy G, Mohamed A (2017) Enhancing seed yield of hybrid rice by maintaining row ratio and dosages of gibberellic acid. Cercetări Agronomice în Moldova 6: 31-45.

Ahmad R, Jabeen N (2009) Demonstration of growth improvement in sunflower (Helianthus annulus L.) by the use of organic fertilizers under saline conditions. Pakistan Journal of Botany 41: 1373-1384.

Akhter MM, Hossain A, Timsina J, Teixeira da Silva JA, Islam MS (2016) Chlorophyll meter - a decision-making tool for nitrogen application in wheat under light soils. International Journal of Plant Production 10 : 289-302.

Ali Q, Ashraf M (2011) Exogenously applied glycinebetaine enhances seed and seed oil quality of maize (Zea mays L.) under water deficit conditions. Environmental and Experimental Botany 71: 249-259.

Ali Q, Ashraf M, Anwar F (2010) Seed composition and seed oil antioxidant activity of maize under water stress. Journal of the American Oil Chemists' Society 87: 1179-1187. doi: 10.1007/s11746-010-1599-5.

Ali Q, Ashraf M, Athar HR (2007) Exogenously applied proline at different growth stages enhances growth of two maize cultivars grown under water deficit conditions. Pakistan Journal of Botany 39: 1133-1144.

Ali Q, Ashraf M, Shahbaz M, Humera H (2008) Ameliorating effect of foliar applied proline on nutrient uptake in water stressed maize (Zea mays L.) plants. Pakistan Journal of Botany 40: 211219.

Amanullah, Iqbal A, Irfanullah, Hidayat Z (2016) Potassium Management for Improving Growth and Grain Yield of Maize (Zea mays L.) under Moisture Stress Condition. Scientific Report 6: 34627. doi: 10.1038/srep34627 . 
Anjorin FB, Adejumo SA, Agboola L, Samuel YD (2016) Proline, soluble sugar, leaf starch and relative water contents of four maize varieties in response to different watering regimes. Cercetări Agronomice în Moldova 49: 51-62.

Anjorin FB, Adejumo SA, Are KS, Ogunniyan DJ (2017) Seedling establishment, biomass yield and water use efficiencies of four maize varieties as influenced by water deficit stress. Cercetări Agronomice în Moldova 50: 21-34.

Anjum F, Wahid A, Javed F, Arshad M (2008) Influence of foliar applied thiurea on flag leaf gas exchange and yield parameters of bread wheat (Triticum aestivum L.) cultivars under salinity and heat stress. International Journal of Agriculture \& Biology 10: 619-626

Anjum SA, Wang LC, Farooq M, Hussain M, Xue LL, Zou CM (2011) Brassinolide application improves the drought tolerance in maize through modulation of enzymatic antioxidants and leaf gas exchange. Journal of Agronomy and Crop Science 197: 177-185. doi:10.1111/j.1439 037X.2010.00459.x.

Araus JL, Sanchez C, Cabrera-Bosquet L (2010) Is heterosis in maize mediated through better water use?. New Phytology 187: 392-406. DOI: 10.1111/j.1469-8137.2010.03276.x.

Arfan M, Athar HR, Ashraf M (2007) Does Exogenous Application of Salicylic Acid Through the Rooting Medium Modulate Growth and Photosynthetic Capacity in Two Differently Adapted Spring Wheat Cultivars Under Salt Stress. Journal of Plant Physiology 164, 685-694.

Ashraf M (2009) Biotechnological approach of improving plant salt tolerance using antioxidants as markers. Biotechnology Advances 27: 84-93.

Ashraf M, Foolad MR (2007) Roles of glycinebetaine and proline in improving plant abiotic stress resistance. Environmental and Experimental Botany 59, 206-216.

Athar HR, Ashraf M (2005) Photosynthesis under drought stress. In: Pessarakli M (Ed.).Handbook of Photosynthesis. Taylor and Francis, New York, Pp. 793-804.

Bahar B, Yildirim M, Barutçular C (2009) Relationships between stomatal conductance and yield components in spring durum wheat under Mediterranean conditions. Notulae Botanicae HortiAgro botanici Cluj-Napoca 37: 45-48. doi.org/10.15835/nbha3723084.

Bänziger M, Edmeades GO, Lafitte HR (2002) Physiological mechanisms contributing to the increased $\mathrm{N}$ stress tolerance of tropical maize selected for drought tolerance. Field Crops Research 75: 223-233.
Barutcular C, Dizlek H, EL- Sabagh A, Sahin T, EL- Sabagh M, Islam MS (2016d) Nutritional quality of maize in response to drought stress during grain-filling stages in mediterranean climate condition. Journal of Experimental Biology and Agricultural Sciences 4: 644-652. DOI: 10.18006/2016.4 (Issue6).644.652.

Barutçular C, EL Sabagh A, Konuskan O, Saneoka H, Yoldash KM (2016a) Evaluation of maize hybrids to terminal drought stress tolerance by defining drought indices. Journal of Experimental Biology and Agricultural Sciences 4 : 610-616.

Barutçular C, EL Sabagh A, Koç M, Ratnasekera D (2017) Relationships between Grain Yield and Physiological Traits of Durum Wheat Varieties under Drought and High Temperature Stress in Mediterranean Conditions. Fresenius Environmental Bulletin $26: 4282-4291$.

Barutçular C, Yıldırım M, Koç M, Akıncı C, Toptaş I, Albayrak O, Tanrikulu A, EL Sabagh A (2016e) Evaluation of SPAD chlorophyll in spring wheat genotypes under different environments. Fresenius Environmental Bulletin 25: 1258-1266.

Barutçular C,Yıldırım M, Koç M, Akıncı C,Tanrıkulu A, EL Sabagh A, Saneoka H, Ueda A, Islam MS, Toptas I, Albayrak O, Tanrikulu A (2016b) Quality traits performance of bread wheat genotypes under drought and heat stress conditions. Fresenius Environmental Bulletin 25 : 1-7.

Barutçular C, Yildirim M, Koc M, Akinci C, Toptac I, Albayrak O, Tanrikulu A, El Sabagh A (2016c) Evaluation of SPAD chlorophyll in spring wheat genotypes under different environments. Fresenius Environmental Bulletin 25: 1258-1266.

Basu S, Roychoudhury A, Saha PP, Sengupta DN (2010) Differential antioxidative responses of indica rice cultivars to drought stress. Plant Growth Regulators 60:51-59.

Bouslama M, Schapaugh WT (1984) Stress tolerance in soybean. Part 1: evaluation of three screening techniques for heat and drought tolerance. Crop Science 24: 933-937.

Boyer CD, Hannah LC (2001) Kernel mutants of corn. In: Hallauer AR (ed) Specialty corns. CRC, Boca Raton, FL. Pp. 131.

Boyer JS, Kramer PJ (1995) Water relations of Plants and Soils. Academic press. San Diego.

Bruce WB, Edmeades GO, Barker TC (2002) Molecular and physiological approaches to maize improvement for drought tolerance. Journal of Experimental Botany 53: 13-25.

Cairns JE, Sanchez C, Vargas M, Ordo nez R, Araus JL (2012a) Dissecting maize productivity: Ideotypes associated with grain 
yield under drought stress and well-watered conditions. Journal of Integrative Plant Biology 54: 1007-1020. doi: 10.1111/j.17447909.2012.01156.x.

Cairns JE, Sonder K, Zaidi PH, Verhulst N, Mahuku G, Babu R (2012b) Maize production in a changing climate. Advances in Agronomy 144: 1-58.

Cakir R (2004) Effect of water stress at different development stages on vegetative and reproductive growth of corn. Field Crops Research 89: 1-16.

Chen P, Haboudane D, Tremblay N, Wang J, Vigneault P, Li B (2010) New spectral indicator assessing the efficiency of crop nitrogen treatment in corn and wheat. Remote Sensing of Environment 114: 1987-1997.

Dodd IC (2003) Hormonal interactions and stomatal responses. Journal of Plant Growth Regulation 22: 32-46.

Dolatabadian A, Modarressanavy SAM, Asilan KS (2010) Effect of ascorbic acid foliar application on yield, yield component and several morphological traits of grain corn under water deficit stress conditions. Notulae Scientia Biologicae 2: 45-50.

Duan B, Yang Y, Lu Y, Korpelainen H, Berninger F, Li C (2007) Interactions between drought stress, $\mathrm{ABA}$ and genotypes in Picea asperata. Journal of Experimental Botany 58: 3025-3036.

Eck HV (1986) Effects of water deficits on yield, yield components, and water use efficiency of irrigated corn. Agronomy Journal 78: 1035-1040.

Azab E (2016) Effect of Water Stress and Biological Fertilization on Maize Growth, Chemical Composition and Productivity in Calcareous Soil. American Journal of Plant Physiology, 11: 1-11.

EL Sabagh A, Abdelaal KhAA, Barutçular C (2017b) Impact of plant originated antioxidants supplementation on growth, yield and quality traits of canola plants (Brassica napus L.) in north nile delta under different irrigation conditions. Journal of Experimental Biology and Agricultural Sciences 5:163.172.

EL Sabagh A, Barutçular C, Islam MS (2017a) Relationships between stomatal conductance and yield under deficit irrigation in maize (Zea mays L.). Journal of Experimental Biology and Agricultural Sciences 5: 15-21.

EL Sabagh A, Barutçular C, Hossain A , Islam MS. 2018. Response Of Maize Hybrids To Drought Tolerance Indices In Relation To Grain Weight. Fresenius Environmental Bulletin, 27 (4): 2476-2482.
EL Sabagh A, Barutçular C, Saneoka H (2015a) Assessment of Drought Tolerance Maize Hybrids at Grain Growth Stage in Mediterranean Area. International Journal of Agricultural and Biosystems Engineering 2: 962-965.

EL Sabagh A, Omar A, Saneoka H, Barutçular C (2015c) Evaluation agronomic traits of canola (Brassica napus L.) under organic, bio- and chemical fertilizers. Dicle University Institute of Natural and Applied Science Journal 4:59-67.

EL Sabagh A, Sorour S, Omar A, Islam MS, Ueda A, Saneoka H, Barutçular C (2015b) Soybean (Glycine max L.) growth enhancement under water stress conditions. International Conference on Chemistry, Agriculture and Biological Science (CABS), Sep. 4-5, 2015, Istanbul, Turkey.

EL Sabagh A, Omar A, Saneoka H, Barutçular C (2016c) Role of integrated use of nitrogen fertilizer sources in improving seed quality of canola (Brassica napus L.). Turkish Journal of Agriculture-Food Science and Technology 4: 73-78.

EL Sabagh A, Abd El-Rasool S, Islam MS, Barutçular C, Omar A (2016b) Improving growth of canola (Brassica napus L.) plants by seed inoculation and inorganic - organic nitrogen fertilization. Asian Journal of Science and Technologies 7: 2283- 2288.

EL Sabagh A, Sorour S, Morsi A, Islam MS, Ueda A, Barutcular C, Arioglu H, Saneoka H (2016a) Role of osmoprotectants and compost application in improving water stress tolerance in soybean (Glycine max L.). International Journal of Current Research 8: 25949-25954.

Elwana MWM, El-Hamahmy MAM (2009) Improved Productivity and Quality Associated with Salicylic Acid Application in Greenhouse Pepper. Scientia Horticulturae 122: 521.

Farooq M, Bramley H, Palta JA, Siddique KHM (2011) Heat stress in wheat during reproductive and grain filling phases. Critical Reviews in Plant Science 30:491-507. doi:10.1080/073552689.2011.615687.

Farooq M, Wahid A, Kobayashi N, Fujita D, Basra SMA (2009) Plant drought stress: effects, mechanisms and management. Agronomy and Sustainable Development 29: 185-212.

Fernandez GCJ (1992) Effective selection criteria for assessing plant stress tolerance. In: Kuo CG (Ed), Proceedings of the International Symposium on Adaptation of Vegetables and other Food Crops in Temperature and Water Stress, Publication, Tainan, Taiwan.

Journal of Experimental Biology and Agriculture Science http://www.jebas.org 
Fischer RA, Maurer R (1978) Drought resistance in spring wheat cultivars. I. Grain yield responses. Australian Journal of Agricultural Research 29, 897-912.

Frederick JR, Camp CR, Bauer PJ (2001) Drought stress effects on branch and main stem seed yield and yield components of determinate soybean. Crop Sciences 41: 759-763.

Gavuzzi P, Rizza F, Palumbo M, Campaline RG, Ricciardi GL, Borghi B (1997) Evaluation of field and laboratory predictors of drought and heat tolerance in winter cereals. Plant Science 77: 523-531.

Genc L, Inalpulat M, Kizil U, Mirik M, Smith SE, Mendes M (2013) Determination of water stress with spectral reflectance on sweet corn (Zea mays L.) using classification tree (CT) Analysis. Zemdirbyste Agriculture 100: 81-90. DOI 10.13080/za.2013.100.011.

Gharib H, Hafez E, EL Sabagh A (2016) Optimized potential of utilization efficiency and productivity in wheat by integrated chemical nitrogen fertilization and simulative compounds. Cercetari Agronomice in Moldova 2 :5-20.

Gharieb AS, Metwally TF, Abou-Khadrah SH, Glela AA, EL Sabagh A (2016) Quality of rice grain is influenced by organic and inorganic sources of nutrients and antioxidant application. Cercetări Agronomice în Moldova, Vol. XLIX ,: 57-68.

Giraudat J, Parcy F, Bertauche N, Gosti F, Leung J, Morris PC, Bouvier-Durand M, Vartanian N (1994) Current advances in abscisic acid action and signaling. Plant Molecular Biology 26: 1557-1577.

Golbashy M, Ebrahimi M, Khavari Khorasani S, Choucan R (2010) Evaluation of drought tolerance of some corn (Zea mays L.) hybrids in Iran. African Journal of Agricultural Research 5: 2714-2719.

Gooding MJ, Ellis RH, Shewry PR (2003) Effects of restrictedwater availability and increased temperature on the grain filling, drying and quality of winter wheat. Journal of Cereal Science 37: 295-309. doi:10.1006/jcrs.2002.0501.

Gunes A, Ali IN, Mehmet Alpaslan, Nuray Cicek, Esra Guneri, Figen Eraslan, Tutku Guzelordu (2005) initials of these names should be abbreviated Effects of exogenously applied salicylic acid on the induction of multiple stress tolerance and mineral nutrition in maize (Zea mays L.). Archives of Agronomy and Soil Science 51:6, 687-695. doi: 10.1080/03650340500336075.

Hammad SAR (2008) Physiological and anatomical studies on drought tolerance of pea plants by application of some natural extracts. Annals of Agricultural Sciences 53: 285-305.
Hartung, W, Zhang J and Davies WJ (1994) Does abscisic acid play a stress physiological role in maize plants growing in heavily compacted soil? Journal of Experimental Botany 45:221-226.

Hassan HM, Arafat EFA, EL Sabagh A ( 2016) Genetic Studies on Agro-Morphological Traits in Rice (Oryza sativa L.) under Water Stress Conditions. Journal of Agricultural Biotechnology 01:76- 84 .

He Y, Li R (2004) Effect of the organo-inorgano-mixed fertilizer application on sugarcane yield and soil enzymatic activity. Sugar Crops China 4: 36-38.

Hossain A, Sarker MAZ, Saifuzzaman M, Teixeira da Silva JA, Lozovskaya MV, Akhter MM (2013) Evaluation of growth, yield, relative performance and heat susceptibility of eight wheat (Triticum aestivum L.) genotypes grown under heat stress. International Journal of Plant Production 7: 615-636.

Ignjatovic-Micic D, Kostadinovic M, Bozinovic S, Andjelkovic V, Vancetovic J (2014) High grain quality accessions within a maize drought tolerant core collection. Scientia Agricola 71: 402409.

Islam MS, Akhter MM, EL Sabagh A, Liu LY, Nguyen NT, Ueda A,Saneoka H (2011) Comparative studies on growth and physiological responses to saline and alkaline stresses of Foxtail millet (Setaria italica L.) and Proso millet (Panicum miliaceum L.). Australian Journal of Crop Science 5:1269-1277.

Izanloo A, Condon AG, Langridge P, Tester M, Schnurbusch T (2008) Different mechanisms of adaptation to cyclic water stress in two South Australian bread wheat cultivars. Journal of Experimental Botany 59: 3327-3346. doi.org/10.1093/jxb/ern199

Jafari A, Paknejad F, Jami M, Ahmadi AL (2009) Evaluation of selection indices for drought tolerance of corn (Zea mays L.) hybrids. International Journal of Plant Production 3, 33-38.

Jiang Q, Roche D, Monaco TA, Hole D (2006) Stomatal conductance is a key parameter to assess limitations to photosynthesis and growth potential in barley genotypes. Plant Biology 8: 515-521. doi: 10.1055/s-2006-923964.

Jiang MY, Zhang JH (2002) Role of abscisic acid in water stress induced antioxidant defense in leaves of maize seedlings. Free Radical Research, 36: 1001-1015.

Kamara AY, Menkir A, Badu-Apraku B, Ibikunle O (2003) The influence of drought stress on growth, yield and yield components of selected maize genotypes. Journal of Agricultural Science 141: 43-50. 
Karasu A, Kucu H, Öz M, Bayram G (2015) The effect of different irrigation water levels on grain yield, yield components and some quality parameters of silage maize (Zea mays Indentata Sturt.) in Marmara Region of Turkey. Notulae Botanicae Horti Agrobotanici Cluj-Napoca 43:138-145.doi.org/ 10.15835/nbha.43.1.9602.

Karimian S, Modares Sanavi SAM, Sepehri A (2005) Effect of water stress at vegetative and generative growth stages in leafy hybrids and commercial corn. Agricultural Research on Water, Soil and Plant 5: 39-51.

Kaya C, Sonmez O, Aydemir S, Dikilitaş M (2013) Mitigation effects of glycinebetaine on oxidative stress and some key growth parameters of maize exposed to salt stress. Turkish Journal of Agriculture and Forestry 37: 188-194.

Koc M, Barutçular C, Tiryakioglu M (2008) Possible heattolerantcultivar improvement through the use of flag leaf gas exchange traitsin a Mediterranean Environment. Journal of the Science of Food and Agriculture 88: 1638-1647. doi:10.1002/jsfa.3261.

Köksal ES (2011) Hyperspectral reflectance data processing through cluster and principal component analysis for estimating irrigation and yield related indicators. Agricultural Water Management 98: 1317-1328.

Kolb PF, Robberecht R (1996) High temperature and drought stress effects on survival of Pinus ponderosa seedlings. Tree Physiology 16: 665-672.

Kovacik, Gruz J, Backor J, Strnad M, Repcak M (2009) Salicylic acid-induced changes to growth and phenolic metabolism in Matricaria chamomilla plants. Plant Cell Reports 28:135-43.

Khalil SE, Nahed G, Aziz A, Bedour LAH (2010) Effect of water stress and ascorbic acid on some morphological and biochemical composition of Ocimum basilicum plant. Journal of American Science 6: 33-46.

Khalili M, Moghaddam M, Kazemi Arbat H, Shakiba MR, Kanooni H, Choukan R (2010) Effect of drought stress on different corn genotypes. Journal of Agricultural Science 2: 67-84.

Khalili M, Naghavi MR, Pour Aboughadareh AR, Talebzadeh J (2012) Evaluating of drought stress tolerance based on selection indices in spring canola cultivars (Brassica napus L.). Journal of Agricultural Science 4: 78-85.

Khan A, Iqbal I, Shah A, Ahmad A, Ibrahim M (2010) Alleviation of adverse effects of salt stress in brassica (Brassica campestris) by pre-sowing seed treatment with ascorbic acid. Journal of Agriculture and Environmental Sciences 7: 557-560.

Khan W, Prithiviraj B, Smith D (2003) Photosynthetic Response of Corn and Soybean to Foliar Application of Salicylates. Journal of Plant Physiology 160, 485-492

Kharrazi MAS, Rad MRN (2011) Evaluation of sorghum genotypes (Sorghum bicolor L. Moench) under drought stress conditions using some stress tolerance indices. African Journal of Biotechnology 10: 13086-13089.

Khodarahmpour Z, Hamidi J (2012) Study of yield and yield components of corn (Zea mays L.) inbred lines to drought stress. African Journal of Biotechnology 11: 3099-3105.

Lan J (1998) Comparison of evaluating methods for agronomic drought resistance in crops. Acta Agric Boreali-occidentalis Sinica $7: 85-87$

Lawlor DW, Cornic G (2002) Photosynthetic carbon assimilation and associated metabolism in relation to water deficits in higher plants. Plant, Cell \& Environment 25 : 275-294.

Lee EA, Tollenaar M (2007) Physiological basis of successful breeding strategies for maize grain yield. Crop Science 47: 202215. Doi: 10.2135/cropsci 2007.04.0010IPBS.

Lee SC, Luan S (2012) ABA signal transduction at the crossroad of biotic and abiotic stress responses. Plant Cell Environ 35: 5360.

Leta T, Ramachandrappa BK, Nanjappa HV, Tulu I (2001) Response of corn (Zea mays L.) to moisture stress at different growth stage in alfisois during summer. Mysore Journal Agricultural Sciences 332: 201-207

Lunde C, Drew PD, Jacobs AK, Tester M (2007) Exclusion of $\mathrm{Na}+$ via sodium ATPase (PpENA1) ensures normal growth of Physcomitrella patens under moderate salt stress. Plant Physiology 144:1786-1796.

Martinez JP, Silva H, Ledent JF, Pinto M (2007) Effect of drought stress on the osmotic adjustment, cell wall elasticity and cell volume of six cultivars of common beans (Phaseolus vulgaris L.). European Journal of Agronomy 26: 30-38.

Mattioli R, Falasca G, Sabatini S, Altamura MM, Costantino P, Trovato M (2009) The proline biosynthetic genes P5CS1 and P5CS2 play overlapping roles in Arabidopsis flower transition but not in embryo development. Physiologia Plantarum 137: 72-85.

Mittler R (2002) Oxidative stress, antioxidants and stress tolerance. Trends in Plant Science 7:405-410. 
Mitra J (2001) Genetics and genetic improvement of drought resistance in crop plants. Current Science 80: 758-762.

Monneveux P, Sanchez C, Tiessen A (2008) Future progress in drought tolerance in maize needs new secondary traits and cross combinations. Journal of Agricultural Science 146: 287-300. Doi: $10.1017 /$ S0021859608007818 P.

Monyo ES, Ejeta G, Rhodes D (1992) Genotypic variation for glycinebetaine in sorghum and its relationship to agronomic and morphological traits. Media 37: 283-286

Moser SB, Feil B, Jampatong S, Stamp P (2006) Effect of preanthesis drought nitrogen fertilizer rate and variety on grain yield, yield components and harvest index of tropical maize. Agricultural Water Management 81: 41-58.

Mostafavi KH, SadeghiGeive H, Dadresan M, Zarabi M (2011) Effects of drought stress on germination indices of corn hybrids (Zea mays L.). International Journal Agricultural Sciences 1 : 10-18.

Munjal R, Rana RK (2003) Evaluation of physiological traits in wheat (Triticum aestivum L.) for terminal high temperature tolerance. In: Proceedings of the Tenth International Wheat Genetics Symposium, Poestum, Italy (Vol. 2, pp. 804-805).

Naghavi MR, Pour-Aboughadareh AR, Khalili M (2013) Evaluation of drought tolerance indices for screening some of corn (Zea mays L.) cultivars under environmental conditions. Notulae Scientia Biologicae 5: 388-393.

Nasim W, Ashfaq A, Tasneem K, Aftab W, Muhammad F, Hussain M, Chaudhry HJ, Muhammad MM, Ahmad S, Hammad HM (2012) Effect of organic and inorganic fertilizer on maize hybrids under agro-environmental conditions of Faisalabad Pakistan. African Journal of Agricultural Research 7 : 2713-2719.

Nayer M, Reza H (2008) Drought-induced Accumulation of Soluble Sugar and Proline in Two Maize Varieties. World Applied Sciences Journal 3: 448- 453.

Nazarli H, Faraji F (2011) Effect of irrigation regimes on Proline, soluble sugar, cat and apx activity in wheat. Cercetări Agronomice în Moldova 44: 148.

Olaniyan AB (2015) Maize panacea for hunger in Nigeria. African Journal of Plant science 9: 155-174.

Pandey RK, Maranville JW, Admou A (2000) Deficit irrigation and nitrogen effects on maize in a Sahelian environment: I. Grain yield and yield components. Agricultural water management, $46: 1-13$.

Preap V, Zalucki MP, Jahn GC (2002) Effect of nitrogen fertilizer and host plant variety on fecundity and early instar survival of Nilaparvata lugens (Stål): immediate response. Proceeding of 4th International Workshop on Inter-Country Forecast. Systemic Management Planthopper in East Asia, 13-15 Nov., 2002. Guilin, China, Published by Rural Development Administration and FAO, 163-180, 226.

Rania MAN, Yasser AM, Dalia MAN (2011) Effect of foliar spray with active yeast extract on morphological, anatomical and yield characteristics of kidney bean (Phaseolus vulgaris L.) Australian Journal of basic and Applied Science 5: 1071-1079.

Rashwan E, Mousa A, EL-Sabagh A, Barutçular C (2016) Yield and Quality Traits of Some Flax Cultivars as Influenced by Different Irrigation Intervals. Journal of Agricultural Science 8:226-240.

Ray JD, Sinclair TR (1997) Stomatal closure of maize hybrids in response to drying soil. Crop Science 37: 803-807. doi:10.2135/cropsci1997.0011183 X003700030018x.

Reddy KR, Henry WB, Seepaul R, Lokhande S, Gajanayake B, Brand D (2013) Exogenous application of glycinebetaine facilitates maize (Zea mays L.) growth under water deficit conditions. American Journal of Experimental Agriculture 3:1-13.

Rehman A, Saleem MF, Safdar ME, Hussain S, Akhtar N (2011) Grain quality, nutrient use efficiency, and bioeconomics of maize under different sowing methods and NPK levels. Chilean Journal of Agricultural Research 71: 586-593. doi:10.4067/S071858392011000400014 .

Reynolds MP, Rebetzke G, Pellegrinesci A, Trethowan R (2006) Dought adaptation in wheat. In: Ribaut JM (Ed.), Drought tolerance in cereals. Haworth Food \& Agricultural Products Press, New York. pp. 402-436.

Rivera-Hernandez B, Carrillo-Avila E, Obrador-Olan JJ, JuarezLopez JF, Aceves-Navarro LA (2010) Morphological quality of sweet corn (Zea mays L.) ears as response to soil moisture tension and phosphate fertilization in Campeche, Mexico. Agricultural Water Management 97: 1365-1374.

Rosielle AA, Hamblin J (1981) Theoretical aspects of selection for yield in stress and non-stress environments. Crop Science 21: 943-946.

Saliendra NZ, Meinzer FC (1991) Symplast volume, turgor, stomatal conductance and growth in relation to osmotic and elastic adjustment in droughted sugarcane. Journal of Experimental Botany 42:1251-9.

Sanjari AGH (2000) Evaluation of yiels stability and source of drought tolerant in wheat cultivars and lines in semi-arid of 
country Proceeding of the Fifth Congress of agronomy science and plant breeding. Kraj. Pp. 165.

Schiop ST, Al Hassan M, Sestras AF, Boscaiu M, Sestras RE, Vicente O (2015) Identification of salt stress biomarkers in romanian carpathian populations of Picea abies (L.) Karst. PLoS ONE10:e2133 doi: 10.1371/journal.pone.0135419.

Setter TL, Brain A, Lannigan F, Melkonian J (2001) Loss of kernel set due to water deficit and shadein maize: Carbohydrate supplies, ABA and cytokinin. Crop Sciences 41: 1530-1540.

Shao HB, Chu LY, Shao MA, Abdul Jaleel C, Hong-Mei M (2008) Higher plant Biology, antioxidants and redox signaling under environmental stresses. Comptes rendus biologies 331: 433441.

Shaw RH (1977) Water use and requirements of maize-a review. Agro-meteorology of the maize crop. WMO Publication 481, World Meteorological Organization, Geneva. Pp. 119-134.

Shoa Hoseini M, Farsi M, Khavari khorasani S (2007) Study of the effect of water deficit stress on yield and yield components of some corn hybrids using path analysis. Majale Danesh Keshavarzi 18: $71-85$.

Songsri P, Jogloy S, Junjittakarn J, Kesmala T, Vorasoot N, Holbrook CC, Patanothai A (2013) Association of stomatal conductance and root distribution with water use efficiency of peanut under different soil water regimes. Australian Journal of Crop Science 7: 948-955.

Stone PJ, Wilson DR, Reid JB, Gillespie RN (2001) Water deficit effects on sweet corn: Water use, radiation use efficiency growth and yield. Australian Journal Agricultural Research 52: 103-113.

Timsina J, Connor DJ (2001) Productivity and management of rice-wheat cropping systems: issues and challenges. Field Crops Research 69: 93-132.
Turhan H, Baser I (2004) In vitro and in vivo water stress in sunflower (Helianthus annuus L.). Helia, 27: 227-236.

Unyayar S, Yuksel K, Unal V (2004) Prolin and ABA levels in two sunflower genotypes subjected to water stress. Bulgarian Journal of Plant Physiology 30:34-47.

Wenkert W, Lemon ER, Sinclair TR (1978) Leaf elongation and turgor pressure in field; Grown soybean. Agronomy Journal 70: 761-764.

Yancey PH, Clark ME, Hand SC, Bowlus RD and Somero GN (1982) Living with water stress: Evolution of osmolyte system. Science 217: 1214-122.

Yazar A, Howell TA, Dusek DA, Copeland KS (1999) Evaluation of crop water stress index for LEPA irrigated corn. Irrigation Science 18: 171-180.

Yazdanpanah S, Baghizadeh A, Abbassi F (2011) The interaction between drought stress and salicylic and ascorbic acid on some biochemical characteristics of Saturej hortensis. African Journal of Agricultural Research 6:798-807.

Zhang LX, Li SX, Liang ZS (2009) Differential plant growth and osmotic effects of two maize (Zea mays L.) cultivars to exogenous glycinebetaine application under drought stress. Plant Growth Regulators 58: 297-305.

Zhao CX, He MR, Wang ZL, Wang YF, Lin Q (2009) Effects of different water availability at post-anthesis stage on grain nutrition and quality in strong-gluten winter wheat. Comptes Rendus Biologies 332: 759-764. doi: 10.1016/j.crvi.2009.03.003.

Zharfa M, Moud AAM, Saffari VR (2011) Relationships between Seedling Growth Rate and Yield of Maize Cultivars under Normal and Water Stress Conditions. Journal of Plant Physiology and Breeding 1: 9-23. 